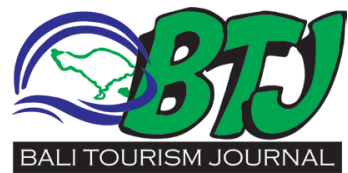

\section{Indonesia to Target Middle East market after King Salman'Visit}

\author{
Ni Ketut Srinadi ${ }^{1}$
}

'Bali Royal Hospital

E-mail:srinadi.ketut79@gmail.com

\section{Editor:}

Ida Bagus Ngurah Tri Pramana, Anak Agung Ngurah Yudistira Apriadi

Received: 23 June 2017 Accepted: 24 July 2017 Published: 28 July 2017

\title{
ABSTRACT
}

Bali is well known as the best tourist destination in the world. Beautiful sceneries along with its distinctive culture become the main attraction of foreign tourists to visit it. During this time, foreign tourists visit Bali is dominated by tourists from Australia and China. While for visitors from the Middle East countries is still relatively small. Middle Eastern tourists are well known as a potential market since they spend a lot of budget for their vacation. On March $4^{\text {th }}$ to $9^{\text {th }} 2017$, Saudi Arabia's King, King Salman Bin Abdul Aziz al Saud traveled to Indonesia with a group of 1500 people. They spend a lot of expenses while holiday in Bali in which gave a good impact on tourism industries in Bali. The King visit is expected to promote Indonesia Tourism especially Bali to his people. Providing information about a halal and friendly destination for tourists from Middle East countries is expected to attract more visitor from those countries. Since their religion is mostly Muslim. By providing detail information about halal tourism information thus it is expected the number of their visit to Indonesia, especially Bali will increase.

Keyword: Middle East Tourist, King Salman, Tourism, Bali

Cite This Article: Ni Ketut Srinadi, Indonesia to Target Middle East market after King Salman' Visit. Bali Tourism Journal (BTJ)2017, 1 (1): $20-23$

\section{INTRODUCTION}

Bali is well known as the best tourist destination in the world. Beautiful sceneries along with its distinctive culture become the main attraction of foreign tourists to visit it. With the high tourist visits to the island of the gods, making the tourism industry as a milestone in the Bali economy. Tourism Promotion is routinely conducted by the government to introduce Bali to the eyes of the world, especially to those potential countries that have 'small visit' to Bali, i.e., countries located in the region of middle east and west Asia. During this time, foreign tourists visit Bali is dominated by tourists from Australia and China ${ }^{1}$.

While for visitors from the Middle East countries is still relatively small. In fact, the market share for tourists from the middle east is very potential, because they are known as royal visitors and always spend a lot of funds for their vacation. From the data of Central Bureau of Statistics, it is known that middle east tourist visit, for instance, Saudi Arabia In December 2016, only reached 8,221 people, while for January 2017 only reached 14,342 people $^{2}$.

\section{KING SALMAN VISIT}

On March 1st, 2017, Saudi Arabia's King, King Salman Bin Abdul Aziz al Saud traveled to Indonesia with a group of 1500 people for bilateral cooperation visit between Indonesia and Saudi
Arabia after the last visit of Saudi Arabia king 47 years ago. After the state visit, King Salman along with his group continued their visit to Bali for a holiday trip. Firstly, their initial plan for the holiday was from March $4^{\text {th }}$ until $9^{\text {th }}$. However, the group finally decided to extend their holiday until March $12^{\text {th }}$. The visit of King Salman to the island of a thousand temples for a holiday received positive responses from various parties, especially in the tourism sector. According to Deputy of Services Distribution and Service Bureau Statistics central, Sasmito Hadi Wibowo mentioned, there would be an enormous multiplier potential from King Salman's visit to Indonesia.

In addition to potentially encouraging foreign tourists from Saudi Arabia, foreign tourists from other Middle Eastern countries are also expected to visit Indonesia on holiday as the king $\mathrm{did}^{2}$.

While in Bali, King Salman hired some luxury facilities from hotels to cars that has quite astonishing charge. With his holiday extension plan, the King's expenses would be fantastic.

Chairman of the Association of Indonesian Travel Companies (ASITA) of Bali Province, I Ketut Ardana, estimates King Salman spend more than Rp 100 billion for his vacation on the Island of the Gods since they stayed at luxury hotels that cost thousand US dollar per night. The number does not include three days extension plan of his vacation period from his initial schedule. 


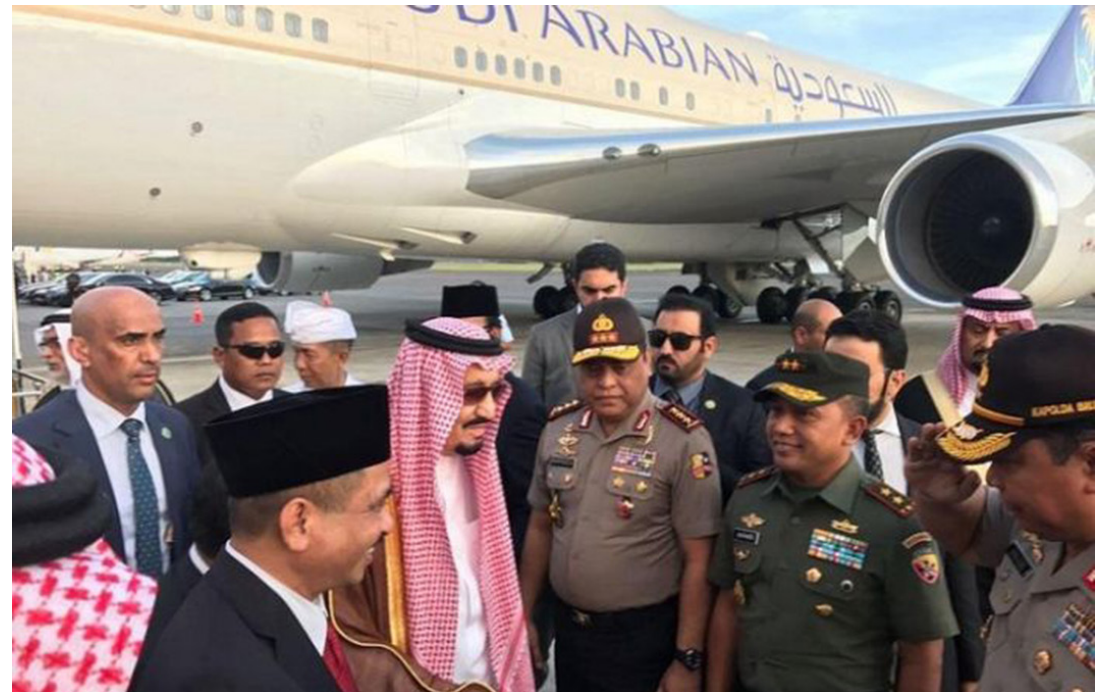

Figure 1 The arrival of King Salman at I Gusti Ngurah Rai Airport on Saturday, March 4th, $2017 .^{4}$

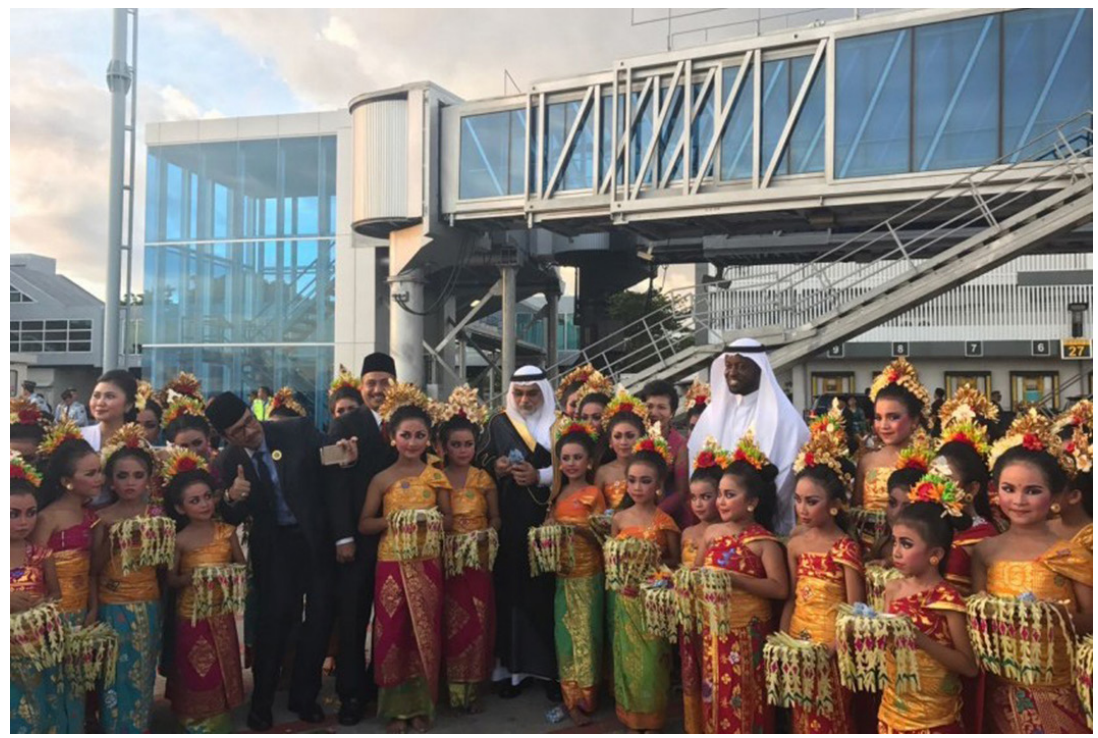

Figure 2 Delegation from Saudi Arabia along with 50 Balinese kid dancers at I Gusti Ngurah Rai International Airport, Saturday ${ }^{9}$

King Salman stayed at the most luxurious hotel in Bali, St. Regis Hotel \& Resort Nusa Dua. All the rooms at the hotel were booked for King Salman and his entourage. The most expensive room rates at St Regis is The Strand Residence room with fantastic rental rates, IDR 73 million per night and Grande Astor Presidential Suite with rent of IDR 36 million per night. Meanwhile, the St Regis rate for suite type rooms ranges from IDR 6.5 million to IDR 11 million per night. As for Room type villa 1 ranges from $\mathrm{Rp} 13$ million to $\mathrm{Rp} 23$ million per night.

Communications and Marketing Director of St. Regis Bali, Esteban Fernandez-Martin, said that St Regis at least provide 123 rooms, consisting of 81 suites and 42 villas Since it is a highly confidential holiday agenda. King Salman is also expected to enjoy the utmost service from the hotel management.

With this estimation, During the nine days of his vacation in Bali, the rate of one hotel was at least reached more than $\mathrm{Rp} 10$ billion. It is a more astonishing fact as King Salman's party hired five luxury hotels while in Bali. Among those luxury hotels, Ritz-Carlton Nusa Dua has room rate for suite type ranging from IDR 5.2 million to IDR 11 million per night. Meanwhile, for villa type has prices ranging from IDR 12.4 million to IDR 31 million per night.

In addition, The Laguna Resort \& Spa provides rooms with rate ranging from IDR 2 million to IDR 8.5 million per night. Rooms offered ranging from deluxe type, executive suites, and pool villa. The Laguna also has special rooms, the Grande Lagoon Suite and Hibiscus Villa.

Besides their fantastic accommodation expenses, it is still followed by luxury vehicles rental rates. Ardana believed for luxury cars the King certainly spent hundreds of billions. King Salman hired luxury cars and 360 units of buses. The details are 200 units of Mercy I-Class type, 20 units of Mercy C-Class, 100 units of Alphard, 20 Land Cruiser units, and 20 buses. One unit of the vehicle is rented at a rate of $\mathrm{Rp} 2.5$ million per day. The total expenditures of the Saudi Arabia Kingdom for transportation for nine days in Bali reach at least Rp 8 billion ${ }^{3}$.

\section{THE ACTIVITIES}

The entourage also took numbers of activities during their vacation in Bali. One of them was water sports in Tanjung Benoa area. Members of the Kingdom of Saudi Arabia was informed tried several water sports activities such as flying fish, jet ski as well diving, with total package price reached IDR 15 Million.

In addition to Benoa, King Salman's entourage also visited Pandawa Beach. The activities they have done on one of the beaches in southern Bali was canoe paddling and spent their time relaxing on the shore. While the King himself relaxed at Geger Beach, which is located opposite the Resort St Regis where he stayed in the area of Nusa Dua. King Salman's entourage was also caught strolling around at Sacred Monkey Forest in Ubud ${ }^{6}$.

The Ubud Monkey Forest is a conservation area, within its boundaries according to the Hindu principle of Tri Hita Karana ("Three ways to reach spiritual and physical well-being"), which seeks to 


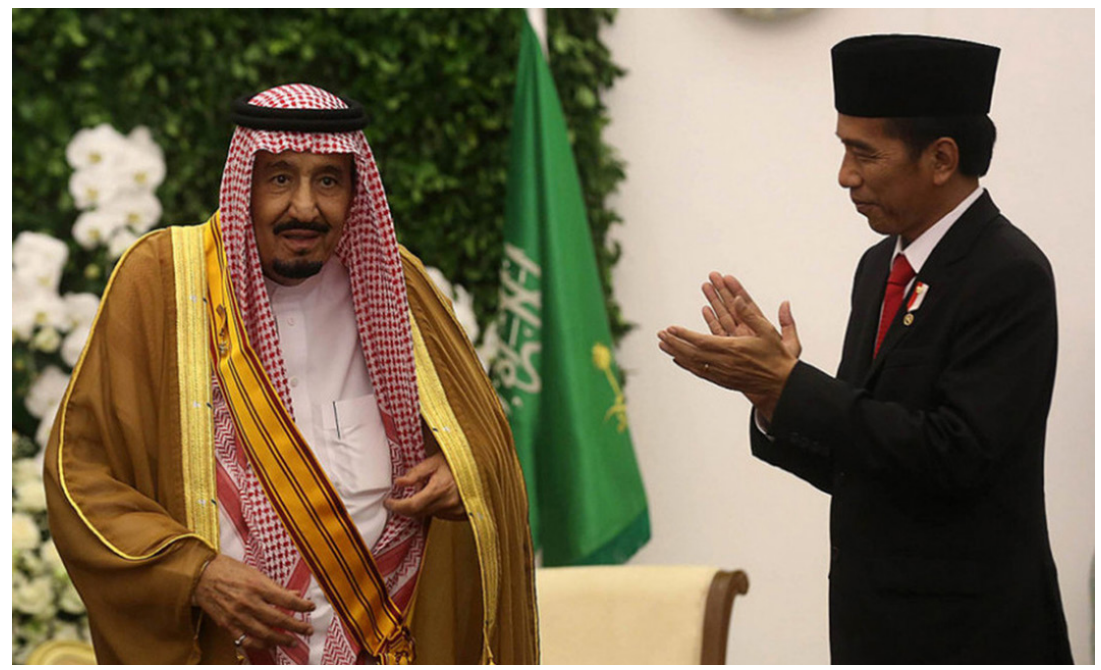

Figure 3 President Joko Widodo (right) applauded after awarding Bintang Adipurna Republic of Indonesia to King Salman bin Abdulaziz Al Saud of Saudi Arabia during his state visit at the Bogor Palace, West Java on March $1^{\text {st }}, 2017$. The award given in recognition of his service in sustaining good relations between two countries ${ }^{5}$

make people live harmoniously during their lives. The "three ways" to this goal under the Tri Hita Karana doctrine are harmonious relationships between humans and humans, between humans and the natural environment, and between human beings and The Supreme God. Accordingly, the Monkey Forest has a philosophical goal of creating peace and harmony for visitors from all over the world. It also seeks to conserve rare plants and animals for use in Hindu rituals and to provide a natural laboratory for educational institutions, with a particular emphasis on research into the social interaction of the park's monkeys with one another and their interaction with the park's natural environment ${ }^{7}$. Prince Khaled bin Badar's entourage spent about 75 minutes in this destination.

The group is also reportedly spending a high budget to shop in the shopping area of the island. For three consecutive days, Saudi royal troupe went to Discovery Shopping Mall in Dewi Sartika street, Kuta, Bali. On March, $8^{\text {th }}$, it was reported more than 80 people bought some souvenirs in the mall which consists of 136 stalls or shops.

Manager PT.Bali Unicon, Wayan Puspa Negara, as the largest mall managers in this Kuta area disclosed the fact. Puspa said that the nominal of goods might be on average above five million rupiahs. However, Puspa admitted he did not know for certain the products of King Salman's entourage. It's just from the invisible entourage entered in a kiosk owned by Billabong, Converse and some
Balinese craft accessories such as statues and some fans.

According to him, since the first time the entourage of Saudi Arabia kingdom came to the mall, they dressed as ordinary tourists. No one wore clothes like in Saudi Arabia. In fact, mostly wearing shorts and T-shirts. Puspa also pointed out about the mall's security that there is no particular security related to the arrival of the shopping group from King Salman' entourage. There was not privileged for them, and the management of mall treated the entourage just like any other visitor ${ }^{8}$.

\section{THE AFTER EFFECT}

After King Salman visit to Bali, The Ministry of Tourism is targeting an increase in the number of Middle Eastern tourists by 50 percent compared to last year. Indonesia is optimistic that the number of tourists is growing after the visit of Saudi Arabia's King Salman Bin Abdul Aziz Al-Saud. Last year, the number of Middle Eastern tourists reached 240 thousand people. That number rose from the previous year which only 150 thousand Middle Eastern tourists. "Then it is boosted again from the middle east." Lastly up 30 percent, this year we rise again to 50 percent or up to 350 thousand people, because King Salman endorses middle eastern tourists, "said Arief after the Global Press Conference Muslim Tourism Index (GMTI) Mastercard-Crescent Rating 2017, Jakarta, Wednesday (3/5).

Moreover, Indonesia is currently a country with the third ranking for Muslim tourist destinations. Arief optimistic the tourists will be more happy to visit the halal and friendly destinations in Indonesia by making technology applications and involve a number of companies. Arief explained the cooperation is also been done to consumers through digital applications. He also mentioned when King Salman came to Indonesia, they used marketing through Al Jazeera television media in the form of advertisement, then continued by Bussiness to Bussiness (B to $B$ ) then Bussiness to Consumer (B to C) promotion.

For example, the digital app will display halal destination information through the location view. In the future, Arief said, there will be a payment system through banking cooperation.

This digital application has been introduced to Middle East tourists and other countries this year. The Ministry of Tourism listed three halal destinations for Muslim tourists including West Nusa Tenggara, West Sumatra, and Aceh ${ }^{10}$. 


\section{CONCLUSION}

Middle East countries are a potential market for tourism promotion since their visit relatively small compared to Australian and Chinese. Moreover, the tourists from middle east countries usually spent a lot of budgets for their holiday in which would give a good impact on tourism industries. For instance, the visit of King Saudi Arabia, King Salman Bin Abdul Aziz al Saud and his entourage. Providing information about a halal and friendly destination for tourists from Middle East countries is expected to attract more visitor from those countries. Since their religion is mostly Muslim. By providing detail information about halal tourism information thus it is expected the number of their visit to Indonesia, especially Bali will increase.

\section{REFERENCES}

1. Dinas Pariwisata Provinsi Bali. http://www.disparda. baliprov.go.id/id/Statistik3. Accessed on 29 July 2017

2. Yoga sukmana. Raja Salman ke Bali, Wisatawan dari Timur Tengah Diharapkan Melonjak. Kompas. 2017. http:// ekonomi.kompas.com/read/2017/03/01/153236326/raja. salman.ke.bali.wisatawan.dari.timur.tengah.diharapkan. melonjak.

3. Mutia Ramadhani. Raja Salman Betah di Bali, Biaya Liburannya Tembus Angka Fantastis.Republika.2017. http://nasional.republika.co.id/berita/nasional/ umum/17/03/09/omi63v382-raja-salman-betah-di-balibiaya-liburannya-tembus-angka-fantastis
4. Anonymous. "Welcoming King Salman in Bali, Who is Father Venus Dewantara?". Documentation of NetralNews. com. 2017. http://www.en.netralnews.com/news/ currentnews/read/2211/welcoming.king.salman.in.bali.. who.is.father.venus.dewantara

5. Anonymous. "Balinese welcomes King Salman". Documentation of Republika. 2017. http://en.republika. co.id/berita/en/national-politics/17/03/05/ombfxg366balinese-welcomes-king-salman

6. Wahyu Setyo Widodo.Mengenang Liburan Raja Salman yang Super Heboh di Bali.Detik News.2017.https://travel. detik.com/domestic-destination/d-3566698/mengenangliburan-raja-salman-yang-super-heboh-di-bali

7. Official Website of Sacred Monkey Forest. http://www. monkeyforestubud.com. accessed on 29 July 2017

8. Gede Nadi Jaya. Belanja di Kuta, rombongan Raja Salman borong kerajinan khas Bali.Merdeka.com. 2017. https://www.merdeka.com/peristiwa/belanja-di-kutarombongan-raja-salman-borong-kerajinan-khas-bali.html

9. Joanito DS. "Raja Salman Dianugerahi Bintang Republik Indonesia Adipurna". BeritaSatu Photo. 2017. http://www. beritasatu.com/dunia/416988-raja-salman-dianugerahibintang-republik-indonesia-adipurna.html

10. Anonymous. Pasca Kunjungan Raja Salman, Wisatawan Timur Tengah Naik 50 Persen. Jawa Pos.2017.http://www. jawapos.com/read/2017/05/04/127659/pasca-kunjunganraja-salman-wisatawan-timur-tengah-naik-50-persen

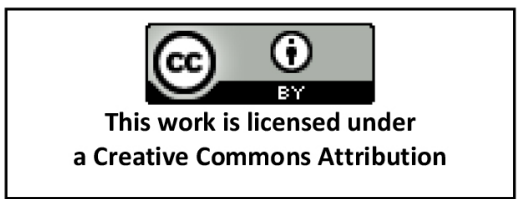

